Article

\title{
Direct Acid Leaching of Sphalerite: An Approach Comparative and Kinetics Analysis
}

\author{
Nallely G. Picazo-Rodríguez ${ }^{1}$, Ma. de Jesus Soria-Aguilar ${ }^{2}$, Antonia Martínez-Luévanos ${ }^{1}$, \\ Isaias Almaguer-Guzmán ${ }^{3}$, Josue Chaidez-Félix ${ }^{3}$ and Francisco Raul Carrillo-Pedroza ${ }^{2, *(D)}$ \\ 1 Facultad de Ciencias Químicas, Universidad Autónoma de Coahuila, República S/N, \\ C.P 25280 Saltillo, Coahuila, Mexico; nallely_pikzo@hotmail.com (N.G.P.-R.); \\ amluevanos@yahoo.com.mx (A.M.-L.) \\ 2 Facultad de Metalurgia, Universidad Autónoma de Coahuila, Carretera 57 Km 5, \\ C.P 25710 Monclova, Coahuila, Mexico; ma.soria@uadec.edu.mx \\ 3 CIDT-SEPSA Peñoles, C.P. 27268 Torreon, Coahuila, Mexico; isaias_almaguer@penoles.com.mx (I.A.-G.); \\ josue_chaidez@penoles.com.mx (J.C.-F.) \\ * Correspondence: raul.carrillo@uadec.edu.mx; Tel.: +52-866-639-0330
}

Received: 26 February 2020; Accepted: 15 April 2020; Published: 17 April 2020

\begin{abstract}
The present work reports the direct leaching of zinc from a sphalerite concentrate in acid media. Lab-scale and pilot-scale experiments were conducted in atmospheric-pressure and low-pressure reactors, respectively. Leaching of zinc and precipitation of iron was achieved in the same stage using different reagents like $\mathrm{Fe}^{3+}, \mathrm{O}_{2}, \mathrm{O}_{3}$, and $\mathrm{Fe}^{2+}$ (which is continuously oxidized in the leaching solution by $\mathrm{H}_{2} \mathrm{O}_{2}$ and $\mathrm{O}_{2}$ ). The highest percentage of zinc extraction $(96 \%)$ was obtained in pilot-scale experiments using $\mathrm{H}_{2} \mathrm{SO}_{4}, \mathrm{Fe}^{2+}$, and $\mathrm{O}_{2}$. Experimental results were compared with those of other researchers to provide a better understanding of the factors influencing the dissolution of zinc. In the first instance, it was determined from analysis of variance that leaching time and the use of an oxidant agent $\left(\mathrm{O}_{2}\right.$ or $\left.\mathrm{O}_{3}\right)$ were the most influential factors during the direct leaching of zinc from the sphalerite concentrate. Kinetic models were also evaluated to determine the rate-limiting step of the sphalerite leaching; it was concluded that the type of the sulfur layer formed in the residue (porous or non-porous) depends on the type of the oxidant used in the leaching media, which determines the dissolution kinetics of zinc.
\end{abstract}

Keywords: zinc; sphalerite; leaching; statistic; kinetics; sulfur layer

\section{Introduction}

Amongst the non-ferrous metals, zinc is one of the most used metals after aluminum and copper. Zinc is an important metal required for many applications, from metal products to chemical, paint, and agriculture industries. It is mainly recovered from sphalerite $(\mathrm{ZnS})$, which is found in metamorphic, igneous, and sedimentary rocks in many parts of the world [1,2].

The conventional method to recover zinc from sphalerite concentrates involves roasting, leaching, precipitation, purification, and electrolysis. The roasting stage transforms metal sulfides into calcines suitable for hydrometallurgical treatment [3-5]. Precipitation of iron is necessary prior to zinc recovery since it causes electrochemical short circuits affecting the electrolytic deposition of zinc [6-8].

Although the conventional method for the recovery of zinc has been used over several years, direct leaching of sphalerite concentrates has recently aroused great interest [9-19]. The direct leaching process omits the roasting stage; in this process, elemental sulfur is produced instead of sulfur dioxide, and effective zinc extraction can be achieved independently of the iron concentration in the zinc concentrates [5]. 
In general, direct leaching processes can be carried out in pressure leaching autoclaves or in agitated tanks operating at atmospheric pressure [20,21]. Atmospheric direct leaching is less expensive than the direct pressure leaching process due to lower maintenance costs [11]. Thereby, there is an increased interest in the use of atmospheric pressure leaching [22]. However, this later is characterized by slow dissolution kinetics. To overcome this shortcoming, researchers have used different oxidants such as ferric ions [12], ozone [22], hydrogen peroxide [23], ammonium, and sodium and potassium persulfate [24].

On the other hand, heterogeneous reactions in which a fluid (gas or liquid) contacts a solid, reacts with it and transforms it into the product, may essentially be represented by the following equation [25]:

$$
\mathrm{A}(\text { fluid })+\mathrm{B}(\text { solid }) \rightarrow \text { product }
$$

Acid leaching follows Equation (1) and can be described by the unreacted shrinking core model [23], where the fluid first reacts with the reactant material at the surface, and then the reaction zone moves inward of the reactant. The unreacted solid sequentially shrinks, while the solid product of the reaction remains or is generally around the same particle and is called ash. The size of the unreacted core decreases as the reaction progresses. In this model, different phases or stages may occur in the reaction with the rate-determining step the one slowest rate in the reaction mechanism [25].

Several kinetic studies of direct leaching of sphalerite, particularly in atmospheric conditions, have demonstrated a two-stage process: A fast leaching rate in the beginning followed by a decrease of the reaction rate after $1 \mathrm{~h}$. The kinetics in the first stage is affected by the chemical reaction and the diffusion rate through the sulfur layer. In this step, the contribution of the chemical reaction decreases gradually as the temperature increases. In the second stage, the rate of sphalerite leaching is controlled only by diffusion through the product layer [26-28].

The effect of the leaching solution composition on the dissolution of zinc from sphalerite ore has been investigated at atmospheric pressure using a ferric sulfate acid solution [12]. It was found that the formed sulfur layer inhibited the reaction due to the formation of a denser layer of elemental sulfur on the particle surface. Other researchers studied the direct leaching of sphalerite at atmospheric pressure and acid media using ozone as oxidant; high extractions of zinc $(\sim 100 \%)$ were obtained accompanied by the formation of a porous sulfur layer [22], which differs from the sulfur layer morphology reported by other researchers [12].

In the present investigation, zinc extraction experiments from a sphalerite concentrate with precipitation of iron using the direct leaching process at lab-scale and pilot-scale were conducted. A parametric study was carried out also using the results obtained by other researchers under different leaching conditions to evaluate the factors influencing the leaching process of zinc concentrates. A kinetic study was also conducted to determine the model and the rate-determining step from the experimental results and other data reported in the literature. It is important to mention that the present work focuses only on the zinc leaching step.

\section{Materials and Methods}

\subsection{Lab-Scale Experiments}

Lab-scale experiments of direct leaching of zinc from sphalerite concentrate $\left(D_{80}\right.$ particle size $=100 \mu \mathrm{m}$ ) were carried out in a $0.5 \mathrm{M}$ sulfuric acid solution at $353 \mathrm{~K}$ under atmospheric pressure. Deionized, distilled water was used in all experiments. Heating was achieved by using a hotplate/stirrer (Thermolyne Cimarec 2, Street Woburn, MA, USA). A 2 L reactor (glass vessel) (Pyrexglass vessel; Corning Inc., New York, NY, USA) was equipped with baffles to prevent swirling of the fluid and fitted with an acrylic sheet cover to minimize loss through evaporation from the leaching solution. The stirring rate remained constant at $500 \mathrm{rpm}$ using a mechanical stirrer type propeller. In some experiments, industrial-grade oxygen $(99.5 \%)$ or ozone $(3 \% \mathrm{w} / \mathrm{w})$, using an ozone generator (Pacific Ozone L23, Pacific Ozone, Benicia, CA, USA), was injected into the leach liquor through a bubbler placed at the bottom of the reactor. Solid residues were characterized by inductively coupled plasma 
optical emission spectrometry (Perkin Elmer 8300, Perkin Elmer, Waltham, MA, USA; LECO SC230DR, LECO Corporation, St. Joseph, MI, USA), and X-ray diffraction analysis was performed using a Brucker D8 diffractometer with $\mathrm{Cu}$ X-ray tube (Bruker, Billerica, MA, USA). Table 1 shows the conditions of experiments conducted at a laboratory scale.

Table 1. Experimental conditions used for the lab-scale experiments of direct leaching of zinc from sphalerite concentrate.

\begin{tabular}{ccc}
\hline Oxidant & {$\left[\mathbf{F e}^{2+}\right], \mathbf{M}$} & Pulp Density, $\mathbf{g} / \mathbf{L}$ \\
\hline $\mathrm{H}_{2} \mathrm{O}_{2}(50 \%)$ & 0.05 & 200 \\
$\mathrm{O}_{2}(99.5 \%)$ & 0.05 & 50 \\
$\mathrm{O}_{3}(3 \%)$ & 0 & 50 \\
$\mathrm{O}_{3}(3 \%)$ & 0.05 & 50 \\
\hline
\end{tabular}

\subsection{Pilot-Scale Experiments}

Pilot-scale experiments of direct leaching of zinc from sphalerite concentrate $\left(\mathrm{D}_{80}\right.$ particle size $=$ $100 \mu \mathrm{m}$ ) were conducted in a $200 \mathrm{~L}, 316 \mathrm{~L}$ stainless steel reactor, which can operate at $0.15 \mathrm{MPa}$. It was equipped with a chemical seal, a stirring system and 4 deflectors, a controlled cooling/heating jacket, a pressure transmitter and resistance temperature detector, and a Graphtec Data logger.

For the experiments, deionized, distilled water was used; boiling water was added to the reactor to reach a temperature of $368 \mathrm{~K}$, followed by a low speed stirring and the addition of all the materials needed for leaching. A 2-min air purge was made after adding the materials, and industrial grade oxygen $(99.5 \%)$ was used to increase the pressure of the reactor to $0.096 \mathrm{MPa}$. It is worth mentioning that in these tests, $\mathrm{NaOH}$ was added in such an amount that iron precipitated as jarosite. Such precipitation occurs, as seen later, once the acid has decreased (from $\mathrm{pH}$ 2) by its consumption in the leaching reaction of sphalerite. In this work only the leaching stage was considered. Finally, the stirring speed was set at $500 \mathrm{rpm}$, before starting the data logger to record data over the leaching time.

To study the kinetics of the leaching process of sphalerite, $100 \mathrm{~mL}$ samples were taken out from the reactor at different times. Liquids was analyzed by inductively coupled plasma optical emission spectrometry (Perkin Elmer 8300 and LECO SC230DR). Solids were characterized by X-ray fluorescence spectrophotometry (Rigaku Primus II, Rigaku, Tokyo, Japan), X-ray diffraction Brucker D8 diffractometer (Brucker) and scanning electron microscopy (FEI Quanta 600, Thermo Fisher Scientific, Waltham, MA, USA). Table 2 shows the conditions of experiments conducted at a pilot-scale.

Table 2. Experimental conditions used at pilot-scale experiments of direct leaching of zinc from sphalerite concentrate.

\begin{tabular}{cccccccc}
\hline Time & Temperature & Agitation Rate & PO2, & \multicolumn{4}{c}{ Pulp Density, } \\
\hline $\mathbf{h}$ & $\mathbf{K}$ & $\mathbf{r p m}$ & $\mathbf{M P a}$ & $\mathbf{M}$ & $\mathbf{g} / \mathbf{L}$ & $\mathbf{M}$ & $\mathbf{M}$ \\
\hline 12 & 368 & 500 & 0.096 & 1.5 & 200 & 0.2 & 0.2 \\
10 & 368 & 500 & 0.096 & 1.5 & 166 & 0.04 & 0.25 \\
5 & 368 & 500 & 0.096 & 1.6 & 140 & 0 & 0 \\
\hline
\end{tabular}

The chemical composition of the sphalerite concentrates (used for both the lab-scale and the pilot-scale experiments) is shown in Table 3.

Table 3. Chemical analysis of sphalerite concentrates (wt.\%).

\begin{tabular}{ccccccccc}
\hline Ag $(\mathrm{g} / \mathrm{t})$ & $\mathrm{Ca}$ & $\mathrm{Cd}$ & $\mathrm{Cu}$ & $\mathrm{Fe}$ & $\mathbf{P b}$ & $\mathrm{S}$ & $\mathrm{Si}$ & $\mathrm{Zn}$ \\
\hline 41.18 & 0.34 & 0.38 & 0.63 & 11.7 & 0.52 & 23.1 & 1.2 & 51.5 \\
\hline
\end{tabular}

Table 4 shows the main species of the zinc concentrates. The mineralogical composition was realized using the HSC 8 (HSC Chemistry Software) Species Converter module [29] with the data 
from the chemical analysis by X-ray fluorescence spectrophotometry and the phases determined by X-ray diffraction.

Table 4. Mineralogical composition of the sphalerite concentrates (wt.\%).

\begin{tabular}{ccc}
\hline \multicolumn{2}{c}{ Identified Species } & Composition (wt.\%) \\
\hline Sphalerite & $(\mathrm{Zn}, \mathrm{Fe}) \mathrm{S}$ & 85 \\
Chalcopyrite & $\mathrm{CuFeS}_{2}$ & 2.0 \\
Pyrite & $\mathrm{FeS}_{2}$ & 1.1 \\
Galena & $\mathrm{PbS}_{\text {Q }}$ & 0.5 \\
Quartz & $\mathrm{SiO}_{2}$ & 2.4 \\
Others & & 9 \\
\hline
\end{tabular}

\section{Results}

\subsection{Statistical Analysis}

In order to study the effects of the experimental conditions on the extraction of zinc from direct leaching of sphalerite, the results obtained in the present work were compared with the results of other researchers. Obviously, mineralogy plays a very important role in hydrometallurgical processes. In this case, direct leaching studies were identified where the concentration of sphalerite was similar, and with no or low presence of marmatite. This meant that the focus was the effect on the leaching parameters and their impact on the formation and characteristics of the sulfur layer. In turn, it was possible to compare the kinetics of the reaction. Tables 5 and 6 show the chemical analysis and mineralogical composition of the sphalerite concentrates used in previous studies that were compared with the present work.

Table 5. Chemical analysis of the sphalerite concentrates (reported in the literature) and that of the sample used for this work.

\begin{tabular}{cccccc}
\hline \multirow{2}{*}{ Sample } & \multicolumn{5}{c}{ Chemical Analysis (wt.\%) } \\
\cline { 2 - 6 } & $\mathbf{Z n}$ & $\mathbf{F e}$ & $\mathbf{C u}$ & $\mathbf{P b}$ & $\mathbf{S}$ \\
\hline Souza et al. [5] & 51.4 & 9.0 & & 1.9 & 31.8 \\
Santos et al. [16] & 42.8 & 9.9 & 2.1 & 1.5 & \\
Karimi et al. [10] & 49.11 & 2.24 & 0.13 & 3.54 & \\
Lampinen et al. [11] & 54.2 & 6.6 & & 1.5 & 30.3 \\
Mubarok et al. [22] & 51.77 & 3.09 & 4.55 & 1.8 & 32.57 \\
\hline
\end{tabular}

Table 6. Mineralogical composition of the sphalerite concentrate (reported in the literature) and that of the sample used for this work.

\begin{tabular}{|c|c|c|c|c|c|}
\hline Sample & Sphalerite, Zns & Pyrite, FeS & Chalcopyrite, $\mathrm{CuFeS}_{2}$ & Galena, PbS & Quartz, $\mathrm{SiO}_{2}$ \\
\hline Souza et al. [5] & 95 & * & * & * & * \\
\hline Santos et al. [16] & 82.2 & 10.8 & 3.6 & * & * \\
\hline Karimi et al. [10] & 73 & $*$ & $*$ & * & * \\
\hline Lampinen et al. [11] & * & 2 & * & 1.8 & * \\
\hline Mubarok et al. [22] & 88 & * & 9.93 & 2.07 & * \\
\hline Pedroza [30] and this work & 85 & * & 2 & 0.5 & 3 \\
\hline
\end{tabular}

Analysis of variance (ANOVA) was conducted to evaluate the individual effect of selected leaching factors on the extraction of zinc. Table 7 shows the factors used for statistical analysis. Factors and levels used for ANOVA were: Leaching time $(2$ and $5 \mathrm{~h})$, reactor type $\left(1=\right.$ opened, $2=$ closed), $\left[\mathrm{H}_{2} \mathrm{SO}_{4}\right]$ $(0.5,1.0,1.5$ and $2 \mathrm{M}),\left[\mathrm{Fe}^{2+}\right](0,0.05,0.2$ and $0.25 \mathrm{M}),\left[\mathrm{Fe}^{3+}\right](0,0.25,0.5$ and $1.2 \mathrm{M}), \mathrm{O}_{2} / \mathrm{O}_{3}(1=$ without oxygen or ozone as oxidants, $2=$ oxygen and $3=$ ozone), temperature $(301,353,363$ and $365 \mathrm{~K})$ and pulp density $(50,100,166$ and $200 \mathrm{~g} / \mathrm{L})$. 
Table 7. Experimental conditions of direct leaching of zinc from sphalerite considered for ANOVA (analysis of variance).

\begin{tabular}{|c|c|c|c|c|c|c|c|c|c|c|c|c|}
\hline Reference & $\begin{array}{l}\text { Type of } \\
\text { Reactor }\end{array}$ & $\begin{array}{c}\text { Pressure } \\
\text { (MPa) }\end{array}$ & Type of Agitator & {$\left[\mathrm{H}_{2} \mathrm{SO}_{4}\right] \mathrm{M}$} & {$\left[\mathrm{Fe}^{2+}\right] \mathrm{M}$} & {$\left[\mathrm{Fe}^{3+}\right] \mathbf{M}$} & $\mathrm{O}_{2} / \mathrm{O}_{3}$ & Particle Size & $\begin{array}{l}\text { Temperature } \\
\text { (K) }\end{array}$ & $\begin{array}{l}\text { Pulp Density } \\
(\mathrm{g} / \mathrm{L})\end{array}$ & $\begin{array}{l}\text { Zn Extraction } \\
\text { after } 2 \mathrm{~h}(\%)\end{array}$ & $\begin{array}{l}\text { Zn Extraction } \\
\text { after } 5 \mathrm{~h}(\%)\end{array}$ \\
\hline Souza et al [5] & 1 & 0.021 & 2 propellers (paddle) & 1 & 0 & 0.5 & 1 & $100 \%<44 \mu \mathrm{m}$ & 363 & 50 & 70 & 90 \\
\hline Santos et al [16] & 1 & 0.021 & 1 propeller (paddle) & 0.5 & 0 & 0.5 & 1 & $99 \%<70 \mu \mathrm{m}$ & 353 & 50 & 90 & 95 \\
\hline Santos et al [16] & 1 & 0.021 & 1 propeller (paddle) & 0.5 & 0 & 0.5 & 1 & $99 \%<70 \mu \mathrm{m}$ & 353 & 100 & 58 & 70 \\
\hline Santos et al [16] & 1 & 0.021 & 1 propeller (paddle) & 0.5 & 0 & 0.25 & 2 & $99 \%<70 \mu \mathrm{m}$ & 353 & 50 & 70 & 80 \\
\hline Karimi et al [10] & 1 & 0.096 & Magnetic & 0.5 & 0 & 1.2 & 1 & $\mathrm{D}_{80}=23.5 \mu \mathrm{m}$ & 353 & 50 & 62 & 80 \\
\hline Lampinen [11] & 2 & 0.49 & 2 propellers (turbine) & 1.5 & 0.05 & 0 & 2 & $\mathrm{D}_{80}=27 \mu \mathrm{m}$ & 368 & 100 & 50 & 85 \\
\hline Mubarok et al [22] & 1 & 0.021 & Magnetic & 2.0 & 0 & 0 & 3 & $100 \%<74 \mu \mathrm{m}$ & 301 & 50 & 50 & 80 \\
\hline Pedroza [30] & 1 & 0.096 & 1 propeller (helix) & 0.5 & 0 & 0.5 & 2 & $D_{80}=100 \mu \mathrm{m}$ & 353 & 50 & 50 & 45 \\
\hline${ }^{*}$ Experiment 1 & 1 & 0.096 & 1 propeller (helix & 0.5 & 0.5 & 0 & 1 & $\mathrm{D}_{80}=100 \mu \mathrm{m}$ & 353 & 200 & 16 & 16 \\
\hline${ }^{*}$ Experiment 2 & 1 & 0.096 & 1 propeller (helix) & 0.5 & 0.5 & 0 & 2 & $\mathrm{D}_{80}=100 \mu \mathrm{m}$ & 353 & 50 & 44 & 50 \\
\hline${ }^{*}$ Experiment 3 & 1 & 0.096 & 1 propeller (helix) & 0.5 & 0 & 0 & 3 & $\mathrm{D}_{80}=100 \mu \mathrm{m}$ & 353 & 50 & 29 & 45 \\
\hline${ }^{*}$ Experiment 4 & 1 & 0.096 & 1 propeller (helix) & 0.5 & 0.5 & 0 & 3 & $\mathrm{D}_{80}=100 \mu \mathrm{m}$ & 353 & 50 & 21 & 34 \\
\hline${ }^{*}$ Experiment 5 & 2 & 0.021 & $\begin{array}{l}2 \text { propellers (paddle } \\
\text { and hélix) }\end{array}$ & 1.5 & 0.2 & 0 & 2 & $\mathrm{D}_{80}=100 \mu \mathrm{m}$ & 368 & 200 & 32 & 59 \\
\hline${ }^{*}$ Experiment 6 & 2 & 0.096 & $\begin{array}{l}2 \text { propellers (paddle } \\
\text { and hélix) }\end{array}$ & 1.5 & 0.25 & 0 & 2 & $\mathrm{D}_{80}=100 \mu \mathrm{m}$ & 368 & 166 & 73 & 96 \\
\hline
\end{tabular}

${ }^{*}$ Experiments conducted in the present work. 
Table 8 presents the main effects as a function of zinc extraction, as determined by ANOVA. According to the F-value and the levels of significance ( $p$-values), it can be stated that under the conditions studied, leaching time was the most influential factor followed by the use of $\mathrm{O}_{2}$ or $\mathrm{O}_{3}$, pulp density, and $\mathrm{Fe}^{3+}$ concentration, which had a similar significant effect.

Table 8. Analysis of variance of data shown in Table 7.

\begin{tabular}{cccccc}
\hline Source of Variance & Degrees of Freedom & Sum Squares & Mean Squares & F-Value & $p$-Value \\
\hline Leaching time, $\mathrm{h}$ & 1 & 1536 & 1536.59 & 14.16 & $5 \times 10^{-3 *}$ \\
Type of reactor & 1 & $4.89 \times 10^{-11}$ & $4.89 \times 10^{-11}$ & 0 & 0.99 \\
Pulp density, g/L & 3 & 1750 & 583.34 & 5.38 & $25 \times 10^{-3 *}$ \\
Temperature, $\mathrm{K}$ & 3 & $8.41 \times 10^{-12}$ & $2.80 \times 10^{-12}$ & 0 & 1 \\
$\mathrm{O}_{2} / \mathrm{O}_{3}$ & 2 & 2415 & 1207.67 & 11.13 & $4 \times 10^{-3 *}$ \\
{$\left[\mathrm{H}_{2} \mathrm{SO}_{4}\right], \mathrm{M}$} & 3 & 821 & 273.91 & 2.52 & 0.13 \\
{$\left[\mathrm{Fe}^{2+}\right], \mathrm{M}$} & 3 & 212 & 70.75 & 0.65 & 0.60 \\
{$\left[\mathrm{Fe}^{3+}\right], \mathrm{M}$} & 3 & 1574 & 524.84 & 4.48 & $0.03^{*}$ \\
\hline
\end{tabular}

* Significance level of alpha $=0.05$.

Figure 1 shows the individual effects of the most significant factors on the extraction of $\mathrm{Zn}$ : Leaching time, non-use or use of $\mathrm{O}_{2}$ or $\mathrm{O}_{3}$, pulp density, and concentration of $\mathrm{Fe}^{3+}$. As can be seen, the efficiency of $\mathrm{Zn}$ extraction increased from $52 \%$ to $65 \%$ when the leaching time was increased from 2 to $5 \mathrm{~h}$ (Figure 1a). Increasing the pulp density from 50 to $166 \mathrm{~g} / \mathrm{L}$ resulted in an increase of the leaching process efficiency from $60 \%$ to $85 \%$, but it decreased up to $30 \%$ for a pulp density of $200 \mathrm{~g} / \mathrm{L}$. This result was consistent with the results of other researchers [16], who reported incomplete dissolution of metals present in the concentrate during autoclave batch-type experiments carried out at atmospheric pressure with high pulp densities. It was suggested that the increase in the percentage of extraction at a pulp density of $166 \mathrm{~g} / \mathrm{L}$ was primarily determined by the change in temperature and type of reactor used. However, at sufficiently high pulp density, diffusion of reactants appears to be limited given the increasing concentration of products of the reaction.
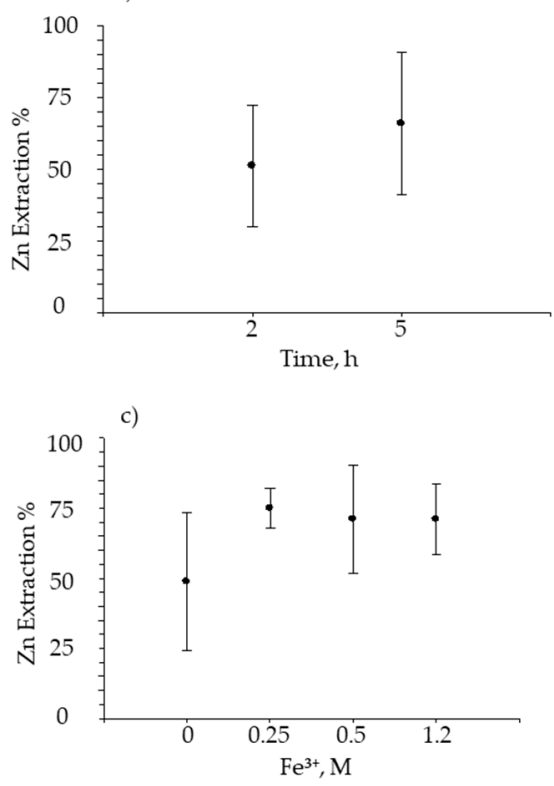

b)

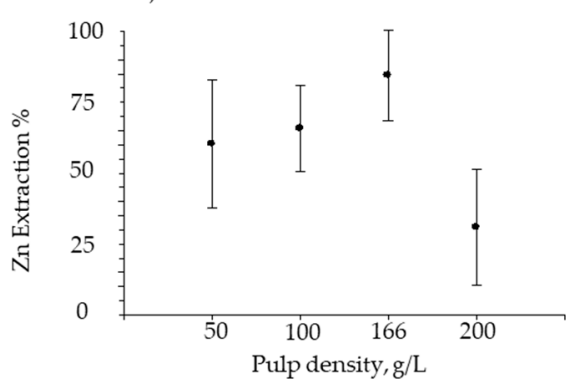

d)

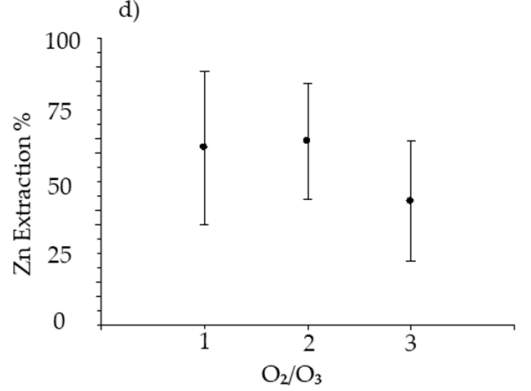

Figure 1. Effect of leaching parameters on the efficiency of zinc extraction: (a) Leaching time, (b) pulp density, (c) $\mathrm{Fe}^{3+}$ concentration, (d) oxidant $\left(1=\right.$ without $\mathrm{O}_{2}$ or $\mathrm{O}_{3}, 2=\mathrm{O}_{2}$ and $\left.3=\mathrm{O}_{3}\right)$. 
With respect to the oxidation of sphalerite, several authors reported the overall chemical reaction of the leaching process [10-19] as follows (Gibbs energy values were obtained from HSC Chemistry 6 [29]:

$$
\begin{gathered}
\mathrm{ZnS}+\mathrm{H}_{2} \mathrm{SO}_{4}+1 / 2 \mathrm{O}_{2}(\mathrm{aq}) \rightarrow \mathrm{ZnSO}_{4}(\mathrm{aq})+\mathrm{S}^{0}+\mathrm{H} 2 \mathrm{O} ; \Delta \mathrm{G}^{\circ}{ }_{80}^{\circ} \mathrm{C}=-251 \mathrm{~kJ} \\
\mathrm{ZnS}+2 \mathrm{H}^{+}+0.5 \mathrm{O}_{2}(\mathrm{aq}) \rightarrow \mathrm{Zn}^{2+}+\mathrm{S}^{0}+\mathrm{H}_{2} \mathrm{O} ; \Delta \mathrm{G}^{\circ} 80^{\circ} \mathrm{C}=-186 \mathrm{~kJ}
\end{gathered}
$$

Some authors [20] reported that leaching of sphalerite occurred mainly according to Equation (2). Other researchers [18] reported that the sphalerite dissolution rate in acid media was controlled by oxygen diffusion through a porous surface layer of polysulfide or $\mathrm{S}^{0}$. In addition, this equation has been represented, as indicated by Equation (3). We can also consider the chemical equilibrium of the species (Figure 2, from Medusa Software) [31].
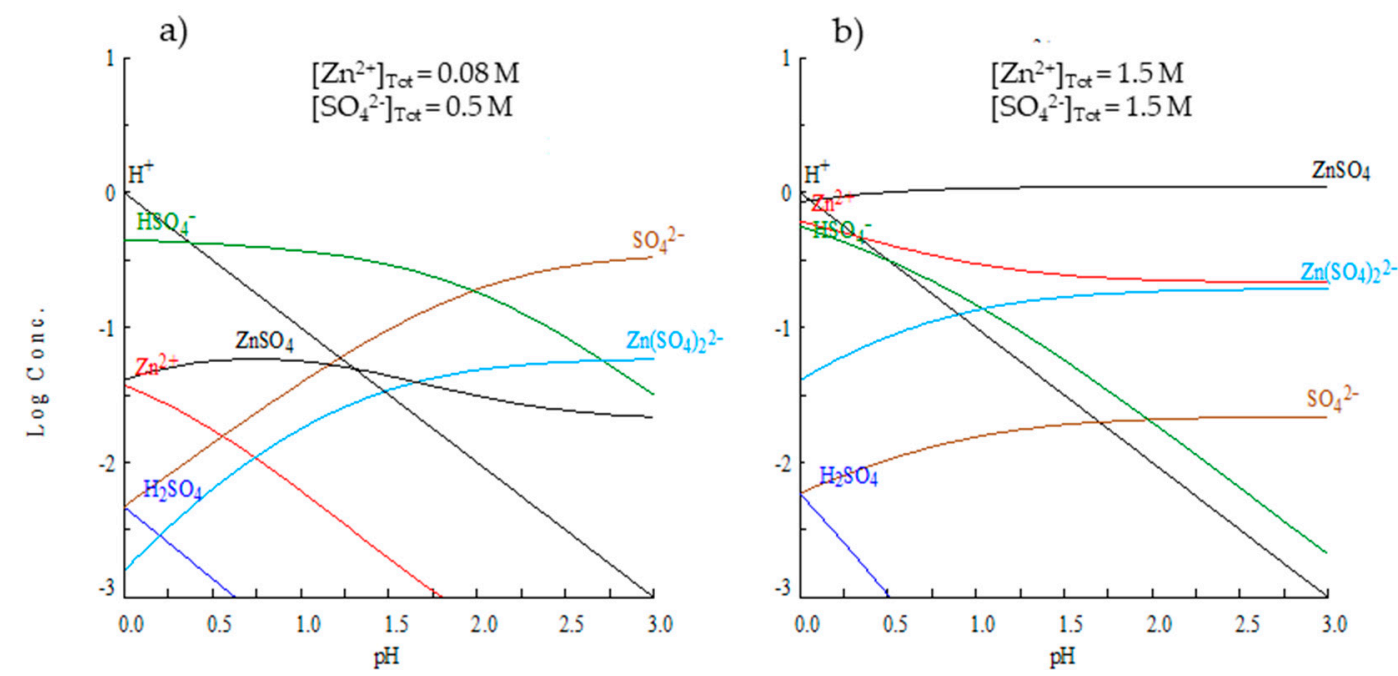

Figure 2. Chemical equilibrium diagrams using Medusa software [31]: (a) Batch-test conditions and (b) pilot test conditions.

According to these figures, the most stable products of sulfuric acid dissociation were $\mathrm{H}^{+}$and $\mathrm{HSO}_{4}{ }^{-}$. In addition, under batch-test conditions (Figure 2a) or equimolar (pilot test) conditions (Figure $2 b$ ), the primary product formed from $\mathrm{ZnS}$ leaching was $\mathrm{ZnSO} 4$ aqueous. Considering these predictions, the following equation is proposed:

$$
\mathrm{ZnS}+\mathrm{H}^{+}+\mathrm{HSO}_{4}{ }^{-}+0.5 \mathrm{O}_{2}(\mathrm{aq}) \rightarrow \mathrm{ZnSO}_{4}(\mathrm{aq})+\mathrm{S}^{0}+\mathrm{H}_{2} \mathrm{O} ; \Delta \mathrm{G}_{80}^{\circ}{ }^{\circ} \mathrm{C}=-188 \mathrm{~kJ}
$$

Therefore, based upon the Gibbs energy, values of Equation (2) and the information given in Figure 2, the leaching of sphalerite was indicated to occur by zinc sulfation and sulfur oxidation. This indicated the involvement of the sulfate ion (or $\mathrm{HSO}_{4}{ }^{-}$anion), which, along with the $\mathrm{ZnSO}_{4}$ ion (both larger molecules), must diffuse through the sulfur layer. Therefore, diffusion of these species can be a limiting step of the reaction.

On the other hand, the chemical theory generally accepted for leaching of ZnS can be described by a process in which ferric sulfate is reduced to ferrous sulfate and elemental sulfur and sphalerite dissolves forming zinc sulfate (aqueous) according to Equation (5) [32,33]. Equation (6) shows only the metallic ion indicating a Gibbs free energy value lower than Equation (5). This indicates that the sulfur is oxidized by the ferric sulfate species, and that the sulfate ion allows the formation of zinc sulfate as aqueous species.

$$
\begin{gathered}
\mathrm{ZnS}+\mathrm{Fe}_{2}\left(\mathrm{SO}_{4}\right)_{3}(\mathrm{aq}) \rightarrow \mathrm{ZnSO}_{4}(\mathrm{aq})+2 \mathrm{FeSO}_{4}(\mathrm{aq})+\mathrm{S}^{0} ; \Delta \mathrm{G}^{\circ} 80^{\circ} \mathrm{C}=-127 \mathrm{~kJ} \\
\mathrm{ZnS}+2 \mathrm{Fe}^{3+} \rightarrow \mathrm{Zn}^{2+}+2 \mathrm{Fe}^{2+}+\mathrm{S}^{0} ; \Delta \mathrm{G}^{\circ}{ }^{\circ}{ }^{\circ} \mathrm{C}=-109 \mathrm{~kJ}
\end{gathered}
$$


Ferrous iron oxidizes to ferric iron in the presence of oxygen, according to Equation (7). However, comparing the energies values between Equations (7) and (8), its shows that the oxidation reaction is more thermodynamically possible in the presence of sulphuric acid rather than just $\mathrm{H}^{+}$.

$$
\begin{gathered}
2 \mathrm{FeSO}_{4}(\mathrm{a})+\mathrm{H}_{2} \mathrm{SO}_{4}+1 / 2 \mathrm{O}_{2}(\mathrm{aq}) \rightarrow \mathrm{Fe}_{2}\left(\mathrm{SO}_{4}\right)_{3}(\mathrm{aq})+\mathrm{H}_{2} \mathrm{O} ; \Delta \mathrm{G}^{\circ}{ }_{80}^{\circ} \mathrm{C}=-124 \mathrm{~kJ} \\
2 \mathrm{Fe}^{2+}+2 \mathrm{H}^{+}+1 / 2 \mathrm{O}_{2}(\mathrm{aq}) \rightarrow 2 \mathrm{Fe}^{3+}+\mathrm{H}_{2} \mathrm{O} ; \Delta \mathrm{G}_{80}^{\circ}{ }^{\circ} \mathrm{C}=-77 \mathrm{~kJ}
\end{gathered}
$$

According to previous equations, ferric iron reacts with $\mathrm{ZnS}$ and is reduced to ferrous ion, which the oxidizes to ferric ion when it reacts with oxygen present in the leaching system; these reaction favor oxidant conditions during leaching [11]. The thermodynamics seems to indicate that the formation of zinc sulfate (aqueous) is more favored than the zinc ion.

As observed in Figure 1c, low zinc extractions (50\%) were obtained in the direct leaching of sphalerite without added $\mathrm{Fe}^{3+}$. However, the efficiency increased up to $75 \%$ with additions of $\mathrm{Fe}^{3+}$; this percentage was independent of the amount of $\mathrm{Fe}^{3+}$ concentration $(0.25 \mathrm{M}$ to $1.2 \mathrm{M})$. Figure $1 \mathrm{~d}$ shows the variations in the zinc extractions as a function of the oxidant $\left(1=\right.$ without $\mathrm{O}_{2}$ or $\mathrm{O}_{3}$ as oxidants, $2=\mathrm{O}_{2}$, and $3=\mathrm{O}_{3}$ ) present in the leaching media. The reactions between the sphalerite and $\mathrm{O}_{2}$ is indicated in Equation (2), while the reaction of sphalerite with $\mathrm{O}_{3}$ occurs according to the following:

$$
\begin{gathered}
\mathrm{ZnS}+\mathrm{H}_{2} \mathrm{SO}_{4}+1 / 3 \mathrm{O}_{3}(\mathrm{aq}) \rightarrow \mathrm{ZnSO}_{4}(\mathrm{aq})+\mathrm{S}^{0}+\mathrm{H}_{2} \mathrm{O} ; \Delta \mathrm{G}^{\circ}{ }_{80}^{\circ} \mathrm{C}=-296.84 \mathrm{~kJ} \\
\mathrm{ZnS}+2 \mathrm{H}^{+}+1 / 3 \mathrm{O}_{3}(\mathrm{aq}) \rightarrow \mathrm{Zn}^{2+}+\mathrm{S}^{0}+\mathrm{H}_{2} \mathrm{O} ; \Delta \mathrm{G}^{\circ} 80^{\circ} \mathrm{C}=-237.48 \mathrm{~kJ}
\end{gathered}
$$

Again, formation of zinc sulfate aqueous (Equation (9)) resulted in a higher Gibbs energy value than the formation of zinc as an ion (Equation (10)). As can be seen, experiments without any gas or with $\mathrm{O} 2$ lead to an average zinc extraction of $65 \%$. On the other hand, the use of O3 (the strongest oxidant) caused a decrease in zinc extraction to $45 \%$. Figure $1 \mathrm{~d}$ shows the average of the extraction results of experiments 3 and 4 (Table 7) and Mubarok et al. [22] tests. It is notable that the latter [22] used ozone without $\mathrm{Fe}^{3+}$ at room temperature, while experiments 3 and 4 were run at $80^{\circ} \mathrm{C}$. The low average zinc extraction may be due to the averaging of data obtained from the use of ozone under high temperature leaching conditions (where the stability and solubility of ozone is lower). The conclusion of Mubarok et al. [22] was that ozone promoted fast oxidation of $\mathrm{Fe}^{2+}$ to $\mathrm{Fe}^{3+}$ and that constant availability of $\mathrm{Fe}^{3+}$ may promote the formation of a non-porous sulfur layer and, therefore, inhibit the extraction of zinc as the reaction proceeds. This and the lower stability of ozone at a higher temperature may explain the low zinc extractions obtained in this study.

\subsection{Kinetic analysis}

The kinetics of the leaching process was determined from zinc extraction data as a function of time obtained from lab-scale experiments (experiment 1 ) and pilot-scale experiments (experiments 5, 6, and 7), and it was described by the shrinking core model.

Table 9 shows a compilation of experimental data obtained in the present work and data reported in the literature made to determine the rate-determining step of the dissolution of zinc under different conditions of leaching.

The rate-limiting step of the zinc dissolution was obtained from a comparison between experimental data and some kinetic models reported in the literature [34], as shown in Table 10. Figure 3 shows the leaching fraction $(X)$ as a function of time for experiments shown in Table 9.

The kinetics analysis was conducted to compare the models reported in the literature using the zinc extraction data (reacted fraction) from Figure 3. Figure 4 shows a comparison of the reaction rate of experiments shown in Table 7, which is represented by the slope corresponding to each curve. It is worth mentioning that this figure was obtained after plotting the corresponding model for each test. The data obtained from each model were normalized in the range of 0 to 1 to be able to visualize and compare the slope of each line. Normalization consisted simply of adjusting the values obtained from 
each model; for example, if the model gave values on the order of $10^{-2}$, it was multiplied by 10 , thus that the values were in the order of $10^{-1}$. In the case of $10^{-3}$, by 100 for the same effect, and so on. Being multiples, the slope of each model was conserved, which allowed a comparison of values of the same order (from $10^{-1}$ ) on the Y-axis. Each slope line was proportional to the apparent constant of the reaction rate of the experiments studied. The higher the slope, the higher the reaction rate. As can be observed, the reaction rate of experiments P1, P2, P5 and P6 was slower than P3, P4, P7, and P8.

Table 9. Experiments of direct leaching of zinc with different initial conditions.

\begin{tabular}{|c|c|c|c|c|c|c|c|c|}
\hline Experiment & Reference & {$\left[\mathrm{Fe}^{3+}\right] \mathrm{M}$} & {$\left[\mathrm{Fe}^{2+}\right] \mathrm{M}$} & {$\left[\mathrm{H}_{2} \mathrm{SO}_{4}\right] \mathrm{M}$} & $\begin{array}{l}\text { Pulp Density } \\
(\mathrm{g} / \mathrm{L})\end{array}$ & $\mathrm{O}_{2} / \mathrm{O}_{3}$ & Particle Size & $\begin{array}{c}\text { Zn Extraction at } \\
5 \mathrm{~h}, \%\end{array}$ \\
\hline P1 & Pedroza [29] & 0.06 & 0 & 0.5 & 60 & None & $\mathrm{D}_{80}=100 \mu \mathrm{m}$ & 47 \\
\hline P2 & Pedroza [29] & 0.05 & 0 & 0.3 & 60 & None & $\mathrm{D}_{80}=100 \mu \mathrm{m}$ & 28 \\
\hline P4 & Experiment $6^{*}$ & 0 & 0.25 & 1.5 & 165.6 & $\mathrm{O}_{2}$ & $\mathrm{D}_{80}=100 \mu \mathrm{m}$ & 96 \\
\hline P5 & Experiment $1^{*}$ & 0 & 0.05 & 0.5 & 200 & None & $\mathrm{D}_{80}=100 \mu \mathrm{m}$ & 16 \\
\hline P6 & Experiment $7^{*}$ & 0 & 0 & 1.6 & 140 & $\mathrm{O}_{2}$ & $\mathrm{D}_{80}=100 \mu \mathrm{m}$ & 9 \\
\hline
\end{tabular}

* Experiments conducted in the present work.

Table 10. Adjustments of kinetic models with experimental data shown in Table 9.

\begin{tabular}{ccccc}
\hline Experiment & Kinetic Model & Description & $\mathbf{k}$ & $\mathbf{R}^{\mathbf{2}}$ \\
\hline P1 & $1-(2 / 3) X-(1-X) 2 / 3$ & Diffusion through a product layer & 0.02 & 0.92 \\
P2 & $1-(1-\mathrm{X}) 2 / 3$ & Diffusion through a thin film & 0.06 & 0.99 \\
P3 & $1-(1-\mathrm{X}) 1 / 3$ & Chemical reaction & 0.06 & 0.96 \\
P4 & $1-(1-\mathrm{X}) 1 / 3$ & Chemical reaction & 0.19 & 0.96 \\
P5 & $(1 /(1-\mathrm{X}) 1 / 3-1) 2$ & Concentration of diffusing species varies with X & 0.001 & 0.95 \\
P6 & $(1 /(1-\mathrm{X}) 1 / 3-1) 2$ & Concentration of diffusing species varies with X & 0.0002 & 0.97 \\
P7 & $1-(1-\mathrm{X}) 1 / 3$ & Chemical reaction & 0.08 & 0.98 \\
P8 & $1-(1-X) 1 / 3$ & Chemical reaction & 0.04 & 0.98 \\
\hline
\end{tabular}

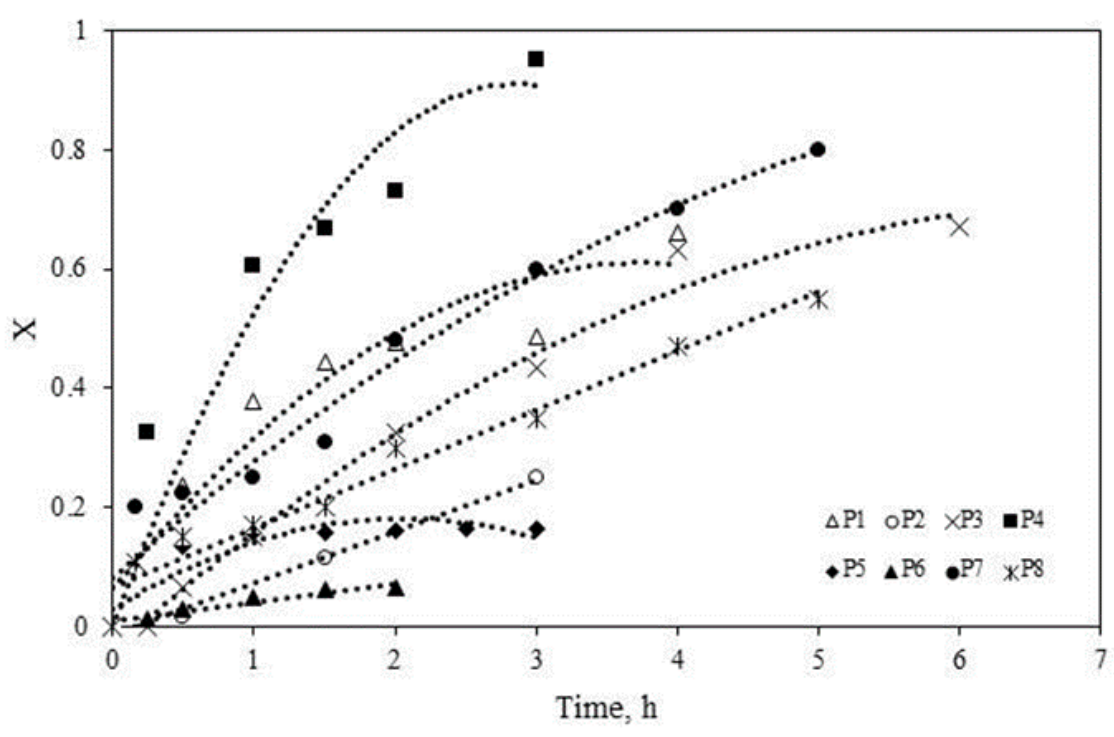

Figure 3. Reacted fraction as a function of time for experiments shown in Table 7. 


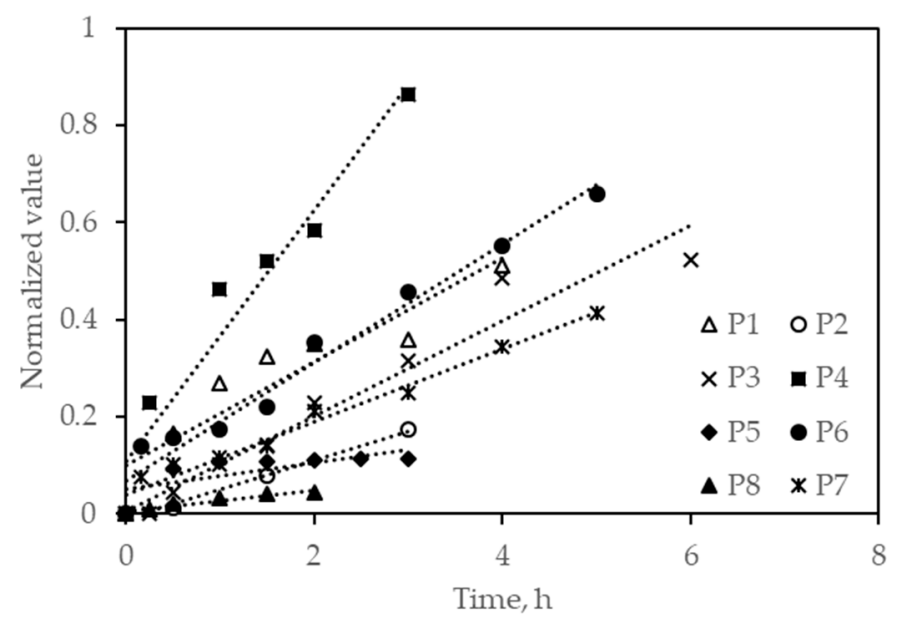

Figure 4. Normalized values of each kinetic model shown in Table 9.

All the experiments presented in Table 9 were adjusted to the shrinking model, however, differences were found in the controlling stages. Experiment P1 fits well to the mechanism that involves the product layer model, according to the following equation.

$$
\mathrm{Kt}=1-(1-X)^{2 / 3}
$$

The kinetics of the leaching process in experiments P5 and P6 (conducted at laboratory scale and at pilot-scale, respectively), is described by the following model:

$$
\mathrm{Kt}=1-(1-\mathrm{X})^{2 / 3}
$$

Some authors have reported that the sphalerite reacts mainly with $\mathrm{Fe}^{3+}$ ions forming a surface product layer, which is probably dense [12,22].

In the case of these experiments, Equations (11) and (12) that represent the oxidation cycle of iron, can be rapid at the beginning, which causes the rapid formation of the elemental sulfur layer due to the type of solid-liquid reaction. As can be seen in Table 7, both tests were conducted in a batch reactor without supplying additional oxygen to the leaching system, therefore, this inhibits the speed of Equations (3) and (4), and consequently, the rate of dissolution of zinc.

Results of experiments $\mathrm{P} 3$ and $\mathrm{P} 4$ carried out at pilot-scale showed that the chemical reaction was the rate-determining step of the direct leaching of sphalerite concentrates. It suggested that the product layer formed at the surface of mineral particles was porous, thin or, that it can be easily detached from the particle and not limiting for the diffusion of reactants and reaction products. The fraction leached as a function of time in these experiments, which exhibited chemically controlled kinetic behavior is expressed as follows:

$$
\mathrm{Kt}=1-(1-X)^{1 / 3}
$$

The kinetics of the leaching process in experiments P5 and P6 (conducted at laboratory scale and at pilot-scale, respectively), is described by the following model:

$$
\mathrm{Kt}=\left(1 /(1-X)^{1 / 3}-1\right)^{2}
$$

This model relates the diffusion process where the concentration of the reactants decreases as the reaction progresses. This can occur when there is a relatively high percentage of solids within the solution.

The use of a high pulp density $(200 \mathrm{~g} / \mathrm{L})$ in experiment $\mathrm{P} 5$ leads to a slow dissolution rate, which may be associated with the low availability of reactants with respect to solids in the leaching media. 
Furthermore, in experiment $\mathrm{P} 5, \mathrm{Fe}^{2+}$ ions were used, without supplying oxygen to the leaching medium, an initial amount of $\mathrm{H}_{2} \mathrm{O}_{2}$ was added, which could have caused the rapid formation of a dense sulfur layer on the surface of the sphalerite particles, in a similar way to experiments P1 and P2.

Experiment P6 conducted in a low-pressure reactor in the presence of sulfuric acid, and oxygen exhibited the presence of H2S. Initially, oxygen consumption was observed; then it stopped, and negative pressure was observed (a characteristic that a gas is leaving the same oxygen inlet line). When purging the line, the $\mathrm{H}_{2} \mathrm{~S}$ gas came out (detected by its smell). Some researchers reported that the dissolution of sphalerite follows the indirect oxidation reactions involving acid dissolution (Equation (15)), the release of H2S, and its further oxidation to elemental sulfur by oxygen or ferric ions (Equation (16)) present in the leaching medium. Therefore, in this case, the chemical reaction in the interface is supposed to be the rate-determining step of the sphalerite leaching process [19].

$$
\begin{gathered}
\mathrm{ZnS}+\mathrm{H}_{2} \mathrm{SO}_{4} \rightarrow \mathrm{ZnSO}_{4}(\mathrm{aq})+\mathrm{H}_{2} \mathrm{~S}(\mathrm{aq}) ; \Delta \mathrm{G}^{\circ}{ }_{95}^{\circ}{ }^{\circ} \mathrm{C}=-37.96 \mathrm{~kJ} \\
\mathrm{H}_{2} \mathrm{~S}(\mathrm{aq})+1 / 2 \mathrm{O}_{2} \rightarrow \mathrm{S} 0+\mathrm{H}_{2} \mathrm{O} ; \Delta \mathrm{G}^{\circ}{ }_{95}^{\circ} \mathrm{C}=-200.05 \mathrm{~kJ} \\
\mathrm{H}_{2} \mathrm{~S}(\mathrm{aq})+\mathrm{Fe}_{2}\left(\mathrm{SO}_{4}\right)_{3}(\mathrm{aq}) \rightarrow \mathrm{H}_{2} \mathrm{SO}_{4}+2 \mathrm{FeSO}_{4}(\mathrm{aq})+\mathrm{S} 0 ; \Delta \mathrm{G}^{\circ}{ }_{95}^{\circ} \mathrm{C}=-93.964 \mathrm{~kJ} \\
\mathrm{H}_{2} \mathrm{~S}(\mathrm{aq})+2 \mathrm{Fe}^{3+} \rightarrow 2 \mathrm{H}^{+}+2 \mathrm{Fe}^{2+}+\mathrm{S} 0 ; \Delta \mathrm{G}^{\circ}{ }_{95}^{\circ} \mathrm{C}=-138.1 \mathrm{~kJ}
\end{gathered}
$$

It is possible that the formation of $\mathrm{H}_{2} \mathrm{~S}$ in experiment $\mathrm{P} 6$ was faster than its oxidation, which may have caused its accumulation in the reactor, making the passage of oxygen difficult and inhibiting the rate of zinc dissolution.

The leaching medium used during experiments P3 and P4 may be the cause of the formation of a porous sulfur layer, since $\mathrm{Fe}^{2+}$ and $\mathrm{O}_{2}$ ions were used. Based on the results of the previous experiments, it was inferred that during the $\mathrm{P} 3$ and $\mathrm{P} 4$ experiments, the reaction of the $\mathrm{Fe}^{3+}$ ions with the sphalerite occurred in a controlled manner, since it involved first the oxidation reaction of $\mathrm{Fe}^{2+}$ to $\mathrm{Fe}^{3+}$ and in secondly the reaction of $\mathrm{Fe}^{3+}$ with the sphalerite. Oxygen (supplied into the pulp) reacts with sphalerite and in the oxidation-reduction cycle of iron, which can be the cause of the pores observed in the sulfur layer, which allows a greater dissolution of zinc. SEM characterization of the leaching residues (P3 and P4 experiments) showed a porous layer of sulfur on the surface of the unreacted sphalerite particles, as shown in Figures 5 and 6.

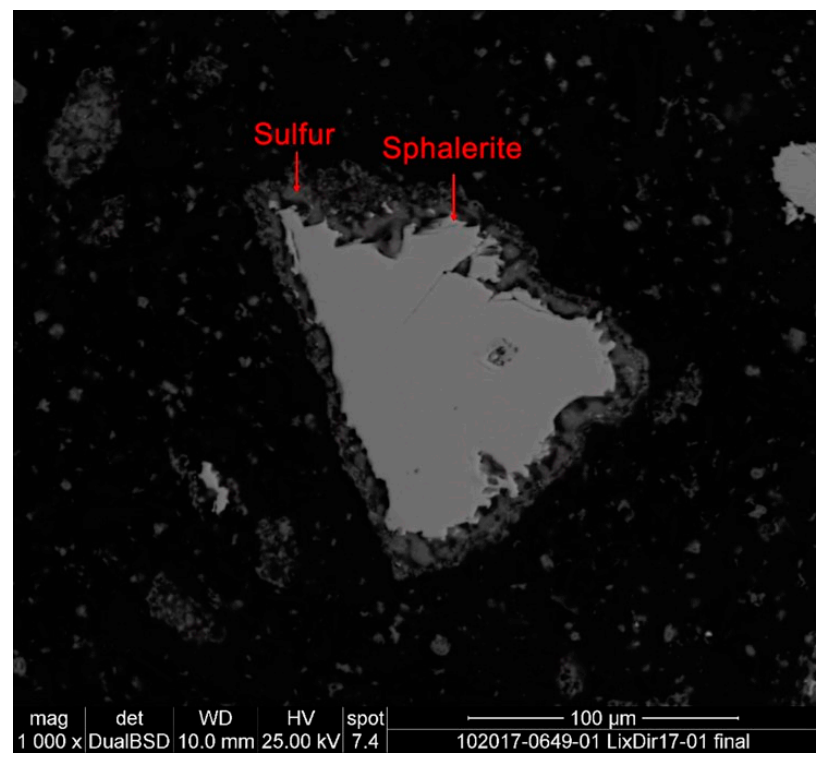

Figure 5. SEM images of leaching residues obtained from experiment P3 showing unreacted sphalerite particles surrounded by elemental sulfur. 


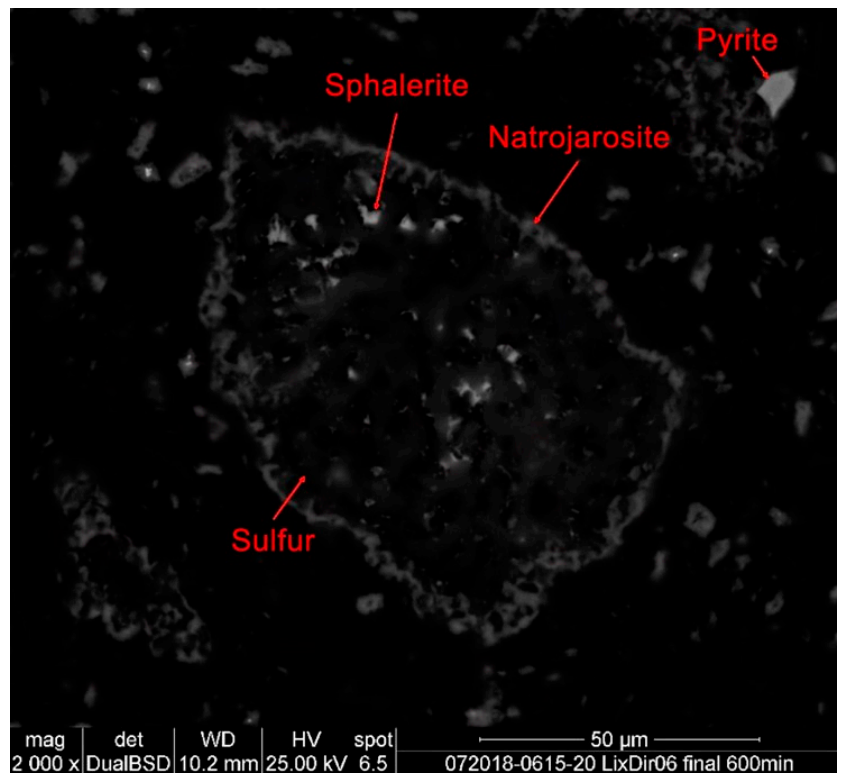

Figure 6. SEM images of leaching residues obtained from experiment $\mathrm{P} 4$ showing the presence of pyrite, sulfur, and sphalerite particles surrounded by natrojarosite.

Cháidez et al. [35] carried out a direct acid leaching of chalcopyrite in the same type of reactor used in experiments $\mathrm{P} 3$ and $\mathrm{P} 4$ and observed a type of porous sulfur layer on unreacted chalcopyrite particles.

Table 11 shows the mineralogical species present in the residue of experiment P4. As can be observed, the percentage of sulfur increases from $3 \%$ at $t=0 \mathrm{~h}$ up to $56 \%$ at $\mathrm{t}=4 \mathrm{~h}$. In addition, despite the formation of a layer of elemental sulfur (apparently porous), $4 \mathrm{~h}$ later, most of the zinc has already been dissolved.

Table 11. Mineralogical reconstruction of leaching residues of experiment P4 obtained at different times.

\begin{tabular}{cccccccccc}
\hline \multirow{2}{*}{ Phases } & \multicolumn{7}{c}{ Composition (wt.\%) } \\
\cline { 2 - 10 } & $\mathbf{t}=\mathbf{0} \mathbf{h}$ & $\mathbf{t}=\mathbf{0 . 1} \mathbf{h}$ & $\mathbf{t}=\mathbf{0 . 2 5} \mathbf{h}$ & $\mathbf{t}=\mathbf{0 . 5} \mathbf{h}$ & $\mathbf{t}=\mathbf{1} \mathbf{h}$ & $\mathbf{t}=\mathbf{1 . 5} \mathbf{h}$ & $\mathbf{t}=\mathbf{2} \mathbf{h}$ & $\mathbf{t}=\mathbf{3} \mathbf{h}$ & $\mathbf{t}=\mathbf{4} \mathbf{h}$ \\
\hline Sphalerite, $(\mathrm{Zn}, \mathrm{Fe}) \mathrm{S}$ & 85 & 77 & 70 & 66 & 58 & 47 & 34 & 21 & 12 \\
Chalcopyrite, $\mathrm{CuFeS}{ }_{2}$ & 2 & 3 & 2 & & & & & & \\
Galena, $\mathrm{PbS}$ & 0.5 & & & & & & & & 4 \\
Pyrite, $\mathrm{FeS}_{2}$ & & 2 & 3 & 3 & 4 & 4 & 4 & 4 & 2 \\
Anglesite, $\mathrm{PbSO}_{4}$ & & 1 & 1 & 1 & 1 & 1 & 2 & 1 & 9 \\
Gypsum, $\mathrm{CaSO}_{4}\left(\mathrm{H}_{2} \mathrm{O}\right)_{2}$ & & & 6 & 8 & 5 & 6 & 11 & 6 & 56 \\
Elemental sulfur, $\mathrm{S}$ & & 3 & 5 & 11 & 19 & 29 & 35 & 46 & 17 \\
Other minerals & 12.5 & 14 & 13 & 11 & 13 & 13 & 14 & 22 & 17 \\
\hline
\end{tabular}

The chemical reaction is also the rate-determining step of experiments P7 and P8 [22]. In these cases, elemental sulfur present in the leaching residue floated easily, forming independent particles, which were released on the mineral surface instead of promoting the formation of layers on the reacted particle. Unlike the atmospheric leaching of sphalerite concentrates with ferric sulfates, there was no apparent obstacle for the dissolution of zinc during the entire leaching process [5,12]. Mubarok et al. [22] also reported that the chemical reaction was the rate-determining step of the sphalerite leaching reaction, which was consistent with the kinetic analysis conducted in the present work.

\section{Conclusions}

Acid leaching of metal sulfides has been extensively studied, mainly chalcopyrite, pyrite, and sphalerite, among other minerals. The consensus in the literature is that the dissolution reaction of the polymetallic sulfides has in common the formation of elemental sulfur. This product is formed around the surface of the mineral. The formed layer may be porous, non-porous, or, in some cases, 
detached from the surface. Therefore, the elemental sulfur layer determines the controlling step of the dissolution reaction of the metal.

In this context, the present study evaluated some of the variables used for sphalerite leaching. The data and results of laboratory and pilot-scale experiments obtained in this work were used and compared with the literature. The analysis of variance (ANOVA) suggests that the use of highly oxidizing conditions can promote the formation of a non-porous layer of sulfur.

In the kinetic study, it was found that when $\mathrm{Fe}^{3+}$ is used as the initial oxidant, the model that limits zinc dissolution is the diffusion of reactants and products, because this oxidant promotes the formation of a layer of non-porous sulfur.

The best result obtained in this work was $96 \%$ zinc extraction after $5 \mathrm{~h}$, which was obtained to pilot-scale in a pressure low-pressure reactor under the following conditions: $353 \mathrm{~K}, 0.096 \mathrm{MPa}$ of pressure, $350 \mathrm{rpm}, 1.5 \mathrm{M} \mathrm{H}_{2} \mathrm{SO}_{4}, 200 \mathrm{~g} / \mathrm{L}$ of pulp density and $0.2 \mathrm{M} \mathrm{Fe}^{2+}$.

The high extraction of zinc obtained in this investigation is related to the reagents used in this case, $\mathrm{Fe}^{2+}$ oxidized with $\mathrm{O}_{2}$ to obtain $\mathrm{Fe}^{3+}$, where the speed of this oxidation reaction is slower than the dissolution of zinc, therefore, this chemical reaction limits the reaction rate. This indicates that the elemental sulfur layer formed is porous, as was demonstrated in the micrographs presented in the results section.

Author Contributions: Conceptualization, I.A.-G. and F.R.C.-P.; methodology, F.R.C.-P., I.A.-G. and N.G.P.-R.; software, N.G.P.-R.; validation, I.A.-G., J.C.-F. and M.d.J.S.-A.; formal analysis, N.G.P.-R., M.d.J.S.-A., F.R.C.-P. and A.M.-L.; investigation, N.G.P.-R.; resources, I.A.-G. and F.R.C.-P.; data curation, M.d.J.S.-A., J.C.-F. and A.M.-L.; writing - original draft preparation, N.G.P.-R.; writing-review and editing, F.R.C.-P.; visualization, F.R.C.-P., I.A.-G., J.C.-F., M.d.J.S.-A. and N.G.P.-R.; supervision, I.A.-G.; project administration, F.R.C.-P. and I.A.-G. All authors have read and agreed to the published version of the manuscript.

Funding: This research received no external funding.

Acknowledgments: Research and Development Center (CIDT-SEPSA) Peñoles supplied the sphalerite concentrate samples, chemical analysis, DRX, and SEM characterization. N. Picazo appreciates the CONACYT scholarship for their PhD thesis.

Conflicts of Interest: The authors declare no conflict of interest.

\section{References}

1. Dutrizac, J.E.; Macdonald, J.C. The dissolution of sphalerite in ferric chloride solution. Metall. Trans. B 1978, 9B, 543-551. [CrossRef]

2. Habashi, F. The Metal Industry Ferrous Metals; WILEY-VCH: Weinheim, Germany, 1997; Volume I.

3. Bobeck, G.E.; Su, H. The kinetics of dissolution of sphalerite in ferric chloride solution. Metall. Trans. B 1985, 16B, 413-424. [CrossRef]

4. Sahu, S.K.; Sahu, K.K.; Pandey, B.D. Leaching of zinc sulfide concentrate from the ganesh-himal deposit of Nepal. Metall. Mater. Trans. B 2006, 37, 541-549. [CrossRef]

5. Souza, A.D.; Pina, P.S.; Leão, V.A. Bioleaching and chemical leaching as an integrated process in the zinc industry. Miner. Eng. 2007, 20, 591-599. [CrossRef]

6. Ismael, M.R.; Carvalho, J.M. Iron recovery from sulphate leach liquors in zinc hydrometallurgy. Miner. Eng. 2003, 16, 31-39. [CrossRef]

7. Sayilgan, E.; Kukrer, T.; Civelekoglu, G.; Ferella, F.; Akcil, A.; Veglio, F.; Kitis, M. A review of technologies for the recovery of metals from spent alkaline and zinc-carbon batteries. Hydrometallurgy 2009, 97, 158-166. [CrossRef]

8. Tsakiridis, P.E.; Oustadakis, P.; Katsiapi, A.; Agatzini, S. Hydrometallurgical process for zinc recovery from electric arc furnace dust (EAFD). Part II: Downstream processing and zinc recovery by electrowinning. J. Hazard. Mater 2010, 179, 8-14. [CrossRef]

9. Dutrizac, J.E. The dissolution of sphalerite in ferric sulfate media. Metall. Mater. Trans. B 2005, 37, 161-171. [CrossRef]

10. Karimi, S.; Rashchi, F.; Moghaddam, J. Parameters optimization and kinetics of direct atmospheric leaching of Angouran sphalerite. Int. J. Miner. Process. 2017, 162, 58-68. [CrossRef] 
11. Lampinen, M.; Laari, A.; Ilkka, T. Kinetic model for direct leaching of zinc sulfide concentrates at high slurry and solute concentration. Hydrometallurgy 2015, 153, 160-169. [CrossRef]

12. Lochmann, J.; Pedlik, M. Kinetic anomalies of dissolution of sphalerite in ferric sulfate solution. Hydrometallurgy 1995, 37, 89-96. [CrossRef]

13. Lorenzo, J.; Iglesias, N.; Romero, R.; Mazuelos, A. Ferric leaching of the sphalerite contained in a bulk concentrate: Kinetic study. Miner. Eng. 2018, 125, 50-59. [CrossRef]

14. Peng, P.; Xie, H.; Lua, L. Coupling leaching of sphalerite concentrate. Miner. Eng. 2005, 18, 553-555. [CrossRef]

15. Santos, S.M.; Ismael, M.R.; Correia, M.J.; Reis, M.T.; Deep, A.; Carvalho, J.M. Hydrometallurgical treatment of a zinc concentrate by atmospheric direct leach process. In Proceedings of the European Congress of Chemical Engineering, Copenhagen, Denmark, 16-20 September 2007; pp. 16-20.

16. Santos, S.M.; Machado, R.M.; Correia, M.J.; Reis, M.T.; Ismael, M.R.; Carvalho, J.M. Ferric sulphate/chloride of zinc and minor elements from a sphalerite concentrate. Miner. Eng. 2010, 23, 606-615. [CrossRef]

17. Svens, K. Direct leaching alternatives for zinc concentrates. In Chen Honorary Symposium on Hydrometallurgy, Electrometallurgy and Aterials Characterization, 1st ed.; Shijie, W., Dutrizac, J.E., Free, M.L., Hwang, J.Y., Kim, D., Eds.; Wiley: Hoboken, NJ, USA, 2012; pp. 191-206. [CrossRef]

18. Weisener, C.G.; Smart, R.S.; Gerson, A.R. A comparison of the kinetics and mechanism of acid leaching of sphalerite conintaining low and high concentrations of iron. Int. J. Miner. Process. 2004, 74, 239-249. [CrossRef]

19. Xu, Z.; Jiang, Q.; Wang, C. Atmospheric oxygen-rich direct leaching behavior of zinc sulphide concentrate. Trans. Nonferrous Met. Soc. China 2013, 23, 3780-3787. [CrossRef]

20. Buban, K.R.; Collins, M.J.; Masters, I.M.; Trytten, L.C. Comparison of direct pressure leaching with atmospheric leaching of zinc concentrates. In Lead-Zinc, 1st ed.; Dutrizac, J.E., Gonzalez, J.A., Henke, D.M., James, S.E., Siegmund, A.H., Eds.; Wiley: Hoboken, NJ, USA, 2000; pp. 727-738. [CrossRef]

21. Lampinen, M.; Laari, A.; Turunen, I. Simulation of direct leaching of zinc concentrate in a CSTR. Can. J. Chem. Eng. 2010, 88, 625-632. [CrossRef]

22. Mubarok, M.Z.; Sukamoto, K.; Ichlas, Z.T.; Sugiarto, A.T. Direct sulfuric acid leaching of zinc sulfide concentrate using ozone as oxidant under atmospheric pressure. Min. Met. Process. 2018, 35, 133-140. [CrossRef]

23. Pecina, T.; Franco, T.; Castillo, P.; Orrantia, E. Leaching of a zinc concentrate in $\mathrm{H}_{2} \mathrm{SO}_{4}$ solutions containing $\mathrm{H}_{2} \mathrm{O}_{2}$ and complexing agents. Miner. Eng. 2008, 21, 23-30. [CrossRef]

24. Babu, M.N.; Sahu, K.K.; Pandey, B.D. Zinc recovery from sphalerite concentrate by direct oxidative leaching with ammonium, sodium and potassium persulphates. Hydrometallurgy 2002, 64, 119-129. [CrossRef]

25. Levenspiel, O. Chemical reaction engineering, 3rd ed.; Wiley: New York, NY, USA, 1999; ISBN 9780471254249.

26. Acero, P.; Cama, J.; Ayora, C. Sphalerite dissolution kinetics in acidic environment. Hydrometallurgy 2007, 22, 1872-1883. [CrossRef]

27. Da Silva, G. Relative importance of diffusion and reaction control during the bacterial and ferric sulphate leaching of zinc sulphide. Hydrometallurgy 2004, 73, 313-324. [CrossRef]

28. Markus, H. Reduction of ferric to ferrous with sphalerite concentrate, kinetic modelling. Hydrometallurgy 2004, 73, 269-282. [CrossRef]

29. Roine, A. HSC Chemistry 8. Available online: www.outotec.com/hsc (accessed on 22 March 2019).

30. Pedroza, S. Estudio de la Reducción y Precipitación de Hierro de la Solución Ácida de la Lixiviación del Zinc. Ph.D. Thesis, Universidad Autómoma de Coahuila, Saltillo, Mexico, 2018.

31. Puigdomenech, I. Medusa Software. Available online: www.kth.se/che/medusa (accessed on 6 April 2020).

32. Corriou, J.P.; Gély, R.; Viers, P. Thermodynamic and kinetic study of the pressure leaching of zinc sulfide in aqueous sulfuric acid. Hydrometallurgy 1988, 21, 85-102. [CrossRef]

33. Dehghan, R.; Noaparast, M.; Kolahdoozan, M.; Mousavi, S.M. Statistical evaluation and optimization of factors affecting the leaching performance of a sphalerite concentrate. Int. J. Miner. Process. 2008, 89, 9-16. [CrossRef]

34. Grénman, H.; Salmi, T.; Murzin, D.Y. Solid-liquid reaction kinetics-experimental aspects and model development. Rev. Chem. Eng. 2011, 27, 53-77. [CrossRef]

35. Cháidez, J.; Parga, J.; Valenzuela, J.; Carrillo, R.; Almaguer, I. Leaching Chalcopyrite Concentrate with Oxygen and Sulfuric Acid Using a Low-Pressure Reactor. Metals 2019, 9, 189. [CrossRef]

(C) 2020 by the authors. Licensee MDPI, Basel, Switzerland. This article is an open access article distributed under the terms and conditions of the Creative Commons Attribution (CC BY) license (http://creativecommons.org/licenses/by/4.0/). 